\title{
Tumour necrosis factor $\alpha$ converting enzyme (TACE) activity in the colonic mucosa of patients with inflammatory bowel disease
}

\author{
J Brynskov, P Foegh, G Pedersen, C Ellervik, T Kirkegaard, A Bingham, T Saermark
}

See end of article for authors' affiliations ........................

Correspondence to: DrJ Brynskov, Department of Medical

Gastroenterology C, Herlev University Hospital, 75 Herlev Ringvej, DK-2730 Herlev, Copenhagen, Denmark;

brynskov@dadlnet.dk

Accepted for publication 20 November 2001
Background: Anti-tumour necrosis factor $\alpha$ (TNF- $\alpha$ ) antibodies are effective in Crohn's disease and perhaps ulcerative colitis but antigenicity and the high cost have raised interest in other strategies to block TNF- $\alpha$. These include the TNF- $\alpha$ converting enzyme (TACE) which releases soluble TNF- $\alpha$ from transmembrane pro-TNF- $\alpha$.

Aim: To investigate whether TACE activity is present in human colonic mucosa.

Materials and methods: Detergent extracts of cell membranes from colonic biopsies were obtained from 12 controls and 28 patients with inflammatory bowel disease. Enzyme activity was measured by hydrolysis assays using pro-TNF- $\alpha$ or oligopeptide substrates spanning the known pro-TNF- $\alpha$ cleavage site at Ala(76)-Val(77). Cleavage products were identified by western blotting, high pressure liquid chromatography, or mass spectrometry. TACE protein was localised by immunohistochemistry and identified by western blotting of detergent extracts from purified lamina propria mononuclear cells (LPMNC) or epithelial cells.

Results: Detergent extracts released TNF- $\alpha$ from pro-TNF- $\alpha$ and cleaved a model oligopeptide as predicted. Substrate hydrolysis was sensitive to known TACE/matrix metalloproteinase (MMP) inhibitors, but not trocade which has low activity against TACE. The median TACE level was increased in active ulcerative colitis (147 arbitrary units $(A U) / \mathrm{mg} ; \mathrm{p}<0.01)$ but not in Crohn's disease $(81 \mathrm{AU} / \mathrm{mg})$ compared with controls $(79 \mathrm{AU} / \mathrm{mg})$. Both the full length proform and the active form of TACE protein were expressed in LPMNC cells and epithelial cells.

Conclusions: Functional TACE activity is ubiquitously expressed in the human colon and increased in ulcerative colitis, raising interest in MMP inhibitors targeting TACE.
$\mathrm{T}$ he therapeutic gain of anti-tumour necrosis factor $\alpha$ $\left(\right.$ TNF- $\alpha$ ) antibody treatment in Crohn's disease, ${ }^{1-7}$ and perhaps also in ulcerative colitis, ${ }^{8}$ indicates that increased levels of TNF- $\alpha$ play a central pathogenic role in inflammatory bowel disease (IBD). Anti-TNF- $\alpha$ antibody treatment is well tolerated but has a number of shortcomings in clinical practice. These include antigenicity of the antibody components, rare occurrence of a lupus-like syndrome, requirement for parenteral administration, and high cost. ${ }^{9}$ These issues have raised interest in the development of alternative therapeutic strategies to block TNF- $\alpha$ activity.

TNF- $\alpha$ is translated as a $26 \mathrm{kDa}$ type II transmembrane precursor protein which requires specific proteolytic cleavage in the extracellular domain at the Ala76-Val77 bond to release the soluble and presumably biologically active $17 \mathrm{kDa}$ $\mathrm{N}$ terminal part of pro-TNF- $\alpha$. The protease responsible for this cleavage has recently been identified as a membrane anchored multidomain metalloproteinase called TNF- $\alpha$ converting enzyme (TACE). ${ }^{10}{ }^{11}$ TACE (ADAM 17) belongs to the ADAM (a disintegrin and metalloproteinase) family of cell surface proteins which are involved in diverse functions such as fertilisation, myogenesis, neurogenesis, neutrophil migration, and ectodomain shedding of cell surface proteins like TNF- $\alpha .{ }^{12-14}$ Northern blot analysis has shown strong expression of mRNA for TACE in several organs such as the heart, placenta, testes, ovaries, and small bowel, whereas weaker expression was observed in libraries of a variety of other human organs, including the colon. ${ }^{10}$

Using the more sensitive reverse transcription-polymerase chain reaction technique, we found that TACE mRNA was ubiquitously expressed in human colonic mucosa and that transcript levels were upregulated in IBD. ${ }^{15}$ Preliminary data also suggested the presence of TACE activity ${ }^{15}$; however, other matrix metalloproteinases (MMP) present in colonic mucosa ${ }^{16-18}$ can also cleave pro-TNF- $\alpha$ in vitro, ${ }^{19}$ and the enzyme responsible for TNF- $\alpha$ release in the colon has not yet been identified. Here, we provide evidence that TACE activity is present in human colonic mucosa and increased in ulcerative colitis.

\section{METHODS \\ Materials}

Oligopeptides with the sequence ac-SPLAQAVRSSSR- $\mathrm{NH}_{2}$ or dinitrophenol (dnp)-SPLAQAVRSSSRTPS- $\mathrm{NH}_{2}$ corresponding to the known pro-TNF- $\alpha$ cleavage site by TACE at Ala (76)-Val (77) were synthesised by commercial solid phase synthesis (KE Jørgensen, Copenhagen, Denmark) and purified in our laboratory using reverse phase high pressure liquid chromatography (HPLC) on a preparative nucleosil $5 \mu \mathrm{C} 18$ column (Pharmacia Biotek, Denmark). Purity was at least 95\%, as

Abbreviations: $A D A M$, a disintegrin and metalloproteinase; $A U$, arbitrary units; BSA, bovine serum albumin; DMSO, dimethylsulphoxide; dnp, dinitrophenol; EDTA, ethylene-diamine-tetraacetic acid; EGTA, ethylene glycol-bis ( $\beta$-aminoethyl ether)- $N, N, N^{\prime}, N^{\prime}$-tetraacetic acid; GST, glutathione-S-transferase; FITC, fluorescein isothiocyanate; HPLC, high pressure liquid chromatography; IBD, inflammatory bowel disease; LPMNC, lamina propria mononuclear cells; MMP, matrix metalloproteinase; MT, membrane type; PBS, phosphate buffered saline; $\mathrm{PE}$, phycoerythrin; SDS, sodium dodecyl sulphate; TACE, TNF- $\alpha$ converting enzyme; TLCK, No-p-tosyl--lysine chloromethyl ketone; TNF- $\alpha$, tumour necrosis factor $\alpha$. 
judged by HPLC analysis. Peptides for identification of breakdown products in HPLC analysis were prepared in the same way. Recombinant human TACE, recombinant glutathione-Stransferase (GST) pro-TNF- $\alpha$ substrate, and the MMP inhibitors $\mathrm{CH} 4474$, BB 94, and trocade, were obtained from Celltech Chiroscience (Cambridge, UK). A goat polyclonal antibody against a peptide mapping the carboxy terminus of human TACE (designated C-15 by the manufacturer) and an epitope specific blocking peptide were obtained from Santa Cruz Biotechnology (UK).

\section{Patients}

Colonoscopic biopsies were obtained from 18 patients with ulcerative colitis and 10 patients with Crohn's disease according to standardised diagnostic criteria. ${ }^{20}{ }^{21}$ Fifteen males and 13 females with a median age of 46 years (range 19-72) were included. Three patients were receiving oral prednisolone (12.5-30 mg/day) at the time of the study and only one was receiving azathioprine $(150 \mathrm{mg} /$ day $)$. Six patients were receiving topical treatment with a prednisolone enema ( $25 \mathrm{mg} /$ day) or a 5-aminosalicylic acid suppository. Twenty four patients were maintained on an oral 5-aminosalicylic acid containing drug (1-3 g/day). Disease activity was graded as described previously. ${ }^{20}$ The control group consisted of three healthy controls and nine patients with no signs of neoplastic or inflammatory disease undergoing routine colonoscopy. Nine males and three females with a median age of 57 years (range 25-78) were studied. In patients with IBD, biopsies were collected from endoscopically inflamed or non-inflamed colonic mucosa, or both, using standard biopsy forceps (Olympus, Japan). Biopsies were immediately washed in isotonic saline and stored in $200 \mu \mathrm{l}$ of Tris buffer at $-80^{\circ} \mathrm{C}$ for later detergent extraction of cell membrane enzyme activity. For western blotting and immunohistochemical studies, biopsies were collected from a further nine control patients, three males and six females, with a median age of 54 years (range 25-73). These biopsies were processed as described below. Permission for collection of biopsies was obtained from the regional ethics committee and all participants gave informed and written consent.

\section{Detergent extraction of TACE activity from cell membranes}

Five biopsies (average $5 \mathrm{mg}$ each) were homogenised by hand in a glass to glass homogeniser (clearance $0.1 \mathrm{~mm}$ ) in $250 \mu \mathrm{l}$ of Tris buffer $(10 \mathrm{mM})$ at $\mathrm{pH}$ 7.5. Crude membranes were separated by precipitation at $15000 \mathrm{~g}_{\mathrm{av}}$ for 20 minutes after a 15 minute incubation period on ice after addition of $\mathrm{CaCl}_{2}$ ( 10 $\mathrm{mM}$ ) to a volume of $1 \mathrm{ml}$. The resulting pellet was dissolved in $50 \mathrm{\mu l}$ of $1 \%$ Nonidet P-40 (Sigma, St Louis, Missouri, USA) at $0-5^{\circ} \mathrm{C}$ for one hour followed by centrifugation at $15000 g_{\text {av }}$ for five minutes. The supernatant used for enzyme analysis is referred to in the following as detergent extract. For initial HPLC experiments, a pool of detergent extract was established from normal colonic tissue obtained in a patient undergoing surgical resection.

\section{Pro-TNF- $\alpha$ hydrolysis assay}

Recombinant human TACE or detergent extract $(0.1 \mathrm{ng})$ was incubated for 60 minutes at $37^{\circ} \mathrm{C}$ with a recombinant GST pro-TNF- $\alpha$ substrate ( $6 \mathrm{ng}$ ) in a total incubation volume of 20 $\mu l$. The incubation volume contained the following buffers: Tris ( $10 \mathrm{mM}, \mathrm{pH} 7.5), \mathrm{MgCl}_{2}(1 \mathrm{mM}), \mathrm{CaCl}_{2}(0.2 \mathrm{mM})$, and protease inhibitors (pepstatin A $(10 \mu \mathrm{M})$, leupeptin $(10 \mu \mathrm{M})$, soybean trypsin inhibitor $(1 \mu \mathrm{g} / \mathrm{ml})$, trasylol (100 units $/ \mathrm{ml})$, and $\alpha$-1-antitrypsin $(0.2 \mathrm{mg} / \mathrm{ml})$ ) (all from Sigma). The inhibitory effects of ethylene-diamine-tetraacetic acid (EDTA) (5 mM), a zinc (and metal) chelating agent, and CH4474 (l $\mu \mathrm{g} / \mathrm{ml})$, a MMP/TACE inhibitor, were studied in separate experiments. ${ }^{22}{ }^{23}$ The reaction was stopped by addition of sam- ple loading electrophoresis buffer $(5 \mu \mathrm{l})$ with sodium dodecyl sulphate (SDS) $(2.5 \%)$ followed by immediate heating to $95^{\circ} \mathrm{C}$. Electrophoresis was performed by application of $4 \mu \mathrm{l}$ samples on a $20 \%$ continuous acrylamide gel using the Phast system (Pharmacia Biotek, Uppsala, Sweden). Western blotting was performed using electrophoretic transfer onto nitrocellulose membranes (Biorad, Sundbyberg, Sweden) followed by inactivation of the nitrocellulose membrane by incubation for one hour in $2 \%$ bovine serum albumin (BSA) (RIA grade; Sigma). Cleavage products of pro-TNF- $\alpha$ were detected by rabbit-anti-GST (AH Diagnostic, Aarhus, Denmark) and rabbit-antihuman TNF- $\alpha$ (Sigma), both diluted 1:4000 in BSA ( $1 \%)$. The secondary goat-antirabbit antibody (Dako, Copenhagen, Denmark) was also diluted 1:4000 in 1\% BSA. Detection was performed with ECL western blotting reagents (Amersham Pharmacia Biotech, Denmark) following the manufacturer's instructions. Gels were photographed using a Polaroid camera designed for the purpose (Amersham, UK).

A modification of the assay was used in separate experiments to study the effect of $N \alpha$-p-tosyl-l-lysinechloromethyl ketone (TLCK), a serine protease inhibitor, on recombinant TACE activity. This assay was based on direct detection of substrate breakdown using silver staining to demonstrate substrate and products. The only other modification was an increase in the amount of GST-pro-TNF- $\alpha$ to 0.5 $\mu g$. Electrophoresis and silver staining were performed according to the manual for the Phast system.

\section{Oligopeptide hydrolysis assays}

Substrate peptide with either the sequence acSPLAQAVRSSSR- $\mathrm{NH}_{2}$ or dnp-SPLAQAVRSSSRTPS- $\mathrm{NH}_{2}(0.5$ $\mu \mathrm{g} / \mathrm{ml}$ ) was added to the incubation medium to start the reaction and incubated at $37^{\circ} \mathrm{C}$ for 60 minutes. The incubation buffer and protease inhibitors were the same as described above. The total incubation volume was $20 \mu \mathrm{l}$ and the sample protein concentration ranged from 3 to $9 \mathrm{mg} / \mathrm{ml}$. Freshly dissolved TLCK $(10 \mu \mathrm{g} / \mathrm{ml})$, the zink chelating agents, phenantrolin $(5 \mathrm{mM})$, and EDTA ( $5 \mathrm{mM}$ ) (without $\mathrm{MgCl}_{2}$ and $\mathrm{CaCl}_{2}$ ), or one of the MMP inhibitors, CH4474 (l $\mu \mathrm{g} / \mathrm{ml}), \mathrm{BB} 94$ (10 $\mu \mathrm{g} / \mathrm{ml})$, or trocade $(5 \mu \mathrm{M})$, were added to the buffer in some experiments. CH4474 and BB94 are broad spectrum MMP inhibitors that also inhibit TACE. In contrast, trocade has only low activity against TACE but inhibits most MMPs. ${ }^{22}{ }^{23} \mathrm{CH} 4474$ or BB94 was reconstituted in dimethylsulphoxide (DMSO) at a final concentration of $0.05 \%$. The same DMSO concentration was used in parallel control experiments. The reaction was stopped by addition of $900 \mu \mathrm{l}$ of $\mathrm{HCl}(0.1 \mathrm{M})$. Peptide breakdown was determined by reverse phase HPLC using a 125×4 mm Machery-Nagle MN-C18 $5 \mu$ silica column (Machery Nagle, Germany). Separation was monitored at $215 \mathrm{~nm}$ for unlabelled peptide substrate, at $340 \mathrm{~nm}$ for dnp labelled peptide substrate, and expressed as arbitrary units (AU) corresponding to the peak area in the chromatogram. The position of the breakdown products was identified by synthetic standards with the predicted sequences for cleavage in the Ala-Val position. The breakdown products from the unlabelled peptide substrate were also identified by mass spectrometry (M-Scan, Oxford, UK). Fractions for this analysis were obtained by fraction collection from the HPLC analysis using peak detection and pooling of samples from 20 analyses. Unpaired and paired data were compared using non-parametric statistical methods.

\section{Immunohistochemistry}

Formalin fixed paraffin embedded tissue sections were dewaxed in xylene for 10 minutes and rehydrated in ethanol. After inhibition of endogenous peroxidase by a solution of hydrogen peroxide in ethanol (30 minutes), sections were heated at $60^{\circ} \mathrm{C}$ overnight in $10 \mathrm{mM}$ Tris $0.25 \mathrm{mM}$ EDTA, pH 9.0. Non-specific reactions with endogenous biotin were 
blocked using a biotin blocking system (Dako), and other non-specific reactions were blocked using Tris buffered saline (0.05 M Tris/HCl, pH 7.6, $0.15 \mathrm{M} \mathrm{NaCl})$ and casein $0.5 \%$. The primary goat anti-TACE antibody (1:1000) was applied for $12-20$ hours at $4^{\circ} \mathrm{C}$. Biotinylated antigoat rabbit immunoglobulin was used as a secondary antibody. Finally, avidin $\mathrm{DH}$ and biotinylated horseradish peroxidase $\mathrm{H}$ reagents (Vector Laboratories, Burlingame, California, USA) were applied and visualised using diaminobenzidine as a chromogen. The reaction was enhanced using biotinylated thyramide followed by further avidin-peroxidase treatment. The nuclei were counterstained with haematoxylin. The specificity of the immunohistochemical analysis was confirmed by substituting the primary antibody with unspecific goat immunoglobulins (Dako) on parallel sections.

\section{Isolation of epithelial cells and lamina propria mononuclear cells}

Colonic epithelial cells were isolated from 5-7 biopsies obtained from endoscopically normal colonic mucosa using short term (10 minutes) EDTA/EGTA (ethylene glycol-bis ( $\beta$-aminoethyl ether)- $N, N, N^{\prime}, N^{\prime}$-tetraacetic acid) treatment, as described in detail recently. ${ }^{24}{ }^{25}$ This method has been shown to release crypts and crypt fragments with less than $5 \%$ contaminating cells. The isolated cells were washed with phosphate buffered saline (PBS) and stored until analysis at $-80^{\circ} \mathrm{C}$ in a buffer containing Tris $(10 \mathrm{mM}, \mathrm{pH} 7.5), \mathrm{MgCl}_{2}(1$ $\mathrm{mM}), \mathrm{CaCl}_{2}(0.2 \mathrm{mM})$, and protease inhibitors (pepstatin A $(10 \mu \mathrm{M})$, leupeptin $(10 \mu \mathrm{M})$, soybean trypsin inhibitor (1 $\mu \mathrm{g} / \mathrm{ml}$ ), trasylol (100 units $/ \mathrm{ml}$ ), and $\alpha$-l-antitrypsin $(0.2$ $\mathrm{mg} / \mathrm{ml})$ ). All reagents were obtained from Sigma.

Lamina propria mononuclear cells (LPMNC) were isolated from 7-10 biopsies, essentially as described previously. ${ }^{26}$ Epithelial cells were removed using 60 minute EDTA/EGTA treatment followed by overnight incubation in the presence of $48 \mathrm{U} / \mathrm{ml}$ type I collagenase (Sigma) in RPMI 1640 medium (Gibco-BRL, UK). LPMNC were separated by passage through a cell strainer ( $100 \mu$ nylon mesh; Falcon, UK), and purified by centrifugation on a Lymphoprep gradient (Nycomed, Norway). Cells were either suspended in $100 \mu \mathrm{l}$ PBS and applied to fluorescent flow cytometry or suspended in a $10 \mu \mathrm{l}$ protease inhibitor buffer (as above) and kept at $-80^{\circ} \mathrm{C}$ for later western blot analysis. Flow cytometry analysis (FAC-Scan; BectonDickinson, Massachusetts, USA) of LPMNC was carried out using fluorescein isothiocyanate (FITC) conjugated or phycoerythrin (PE) conjugated antibodies against CD45 (PE) or CD68 (FITC) (Dako). In a representative experiment, $>95 \%$ of 50000 cells counted were CD45 positive. Further analysis showed a total of $42 \%$ lymphocytes estimated by forward scatter and side scatter (cell size and granulation) and 32\% monocytes/macrophages.

\section{Western blotting of TACE protein}

Colonic epithelial cells or LPMNC were homogenised in 1\% Nonidet P40 (Sigma) in a total volume of $50 \mu l$, which included the same protease inhibitor cocktail as described in the cell isolation procedure, $1 \mathrm{mM}$ EDTA and phenyl methyl sulphonyl fluoride (Sigma). After incubation for 60 minutes at $0^{\circ} \mathrm{C}$, undissolved membranes were removed by centrifugation and the supernatant was used for SDS electrophoresis. In order to ensure sufficient amounts of protein, cells were pooled from $2-5$ individual patients. Total protein $(50 \mu \mathrm{g})$ was separated by electrophoresis on a 4-12\% SDS gel and transferred onto ethanol activated polyvinylidene difluoride membranes (Amersham Pharmacia Biotech). The membranes were blocked for one hour in Tris $10 \mathrm{mM}, \mathrm{NaCl} 0.15 \mathrm{M}$, and $0.05 \%$ Tween-20 supplemented with $2 \%$ BSA and incubated overnight at $4^{\circ} \mathrm{C}$ with anti-TACE antibody diluted 1:5000. After additional washes in buffer, the membrane was incubated for one hour at room temperature with horseradish

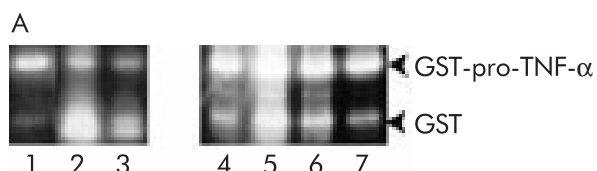

B

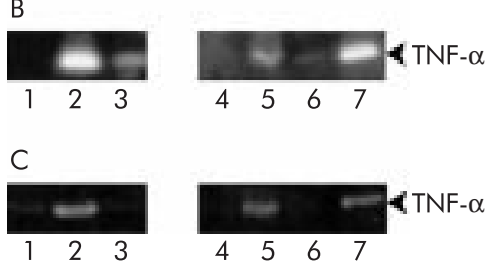

Figure 1 Sodium dodecyl sulphate electrophoresis showing hydrolysis of glutathione-S-transferase-pro-tumour necrosis factor $\alpha$ (GST-pro-TNF- $\alpha$ ) by recombinant TNF- $\alpha$ converting enzyme (TACE) or detergent extract of cell membranes from human colonic mucosa. Bands were visualised by western blotting using antibodies against GST (A) or TNF- $\alpha(B, C)$. Lane 1: recombinant TACE, $t=0$ minutes; lane 2: recombinant TACE, $\mathrm{t}=60$ minutes; lane 3: recombinant TACE, $\mathrm{t}=60$ minutes + inhibitor (EDTA $5 \mathrm{mM}(\mathrm{A}, \mathrm{B}), \mathrm{CH} 44741$ $\mathrm{\mu g} / \mathrm{ml}(\mathrm{C}))$; lane 4 : detergent extract, $\mathrm{t}=0$ minutes; lane 5 : detergent extract, $t=60$ minutes; lane 6 : detergent extract, $t=60$ minutes + inhibitor (EDTA $5 \mathrm{mM}(\mathrm{A}, \mathrm{B}), \mathrm{CH} 4474 \mathrm{l} \mathrm{g} / \mathrm{ml}$ (C)); lane 7: purified standards. Similar results were obtained in two further independent experiments.

peroxidase conjugated antigoat rabbit antibody (Dako) diluted 1:20 000. Detection was performed with ECL western blotting reagents (Amersham Pharmacia Biotech) following the manufacturer's instructions. Gels were photographed using a Polaroid camera designed for the purpose (Amersham, UK). In control experiments the TACE antibody was incubated for two hours at room temperature with an epitope mimicking blocking peptide prior to incubation with membrane protein.

\section{RESULTS}

Demonstration of TACE activity in colonic biopsies using a recombinant pro-TNF- $\alpha$ assay and an unlabelled oligopeptide hydrolysis assay

Figure 1 (A, B) shows that detergent extract of cell membranes isolated from normal colonic mucosa cleaved a recombinant GST-pro-TNF- $\alpha$ substrate into a GST fragment and a TNF- $\alpha$ fragment, as identified by antibodies and standards. The GST fragment was sometimes seen as a double band, probably due to the action of other proteases. Similar results were obtained when recombinant TACE was used to cleave the substrate, and both processes were sensitive to inhibition with EDTA (fig 1A, B) and CH4474, a TACE/MMP inhibitor (fig lC). To determine the precise cleavage site of pro-TNF- $\alpha$ by TACElike activity in detergent extracts, an assay based on cleavage of an unlabelled synthetic peptide mimicking the known proTNF- $\alpha$ cleavage site was devised. As shown in fig 2 (A, B), the oligopeptide substrate was cleaved by detergent extracts yielding two products identified by HPLC. Also, this process was inhibited by EDTA and CH4474 (fig 2C, D). The molecular weight of the resulting peptides produced by cleavage of the model substrate deviated $<2 \%$ from predicted. This indicates that cleavage occurred between $\mathrm{Ala}(76)$ and $\mathrm{Val}(77)$ in the corresponding pro-TNF- $\alpha$ sequence. Deviation should be $>10 \%$ if cleavage shifts one amino acid.

\section{Characterisation of TACE activity in human colonic mucosa using a dnp labelled oligopeptide hydrolysis assay}

A modified assay allowing detection at $340 \mathrm{~nm}$ was required to study the effect of additional protease inhibitors, as some of these interfered with HPLC detection of unlabelled peptide breakdown due to high absorbance in the relevant concentration ranges (data not shown). The reaction was linear for both 

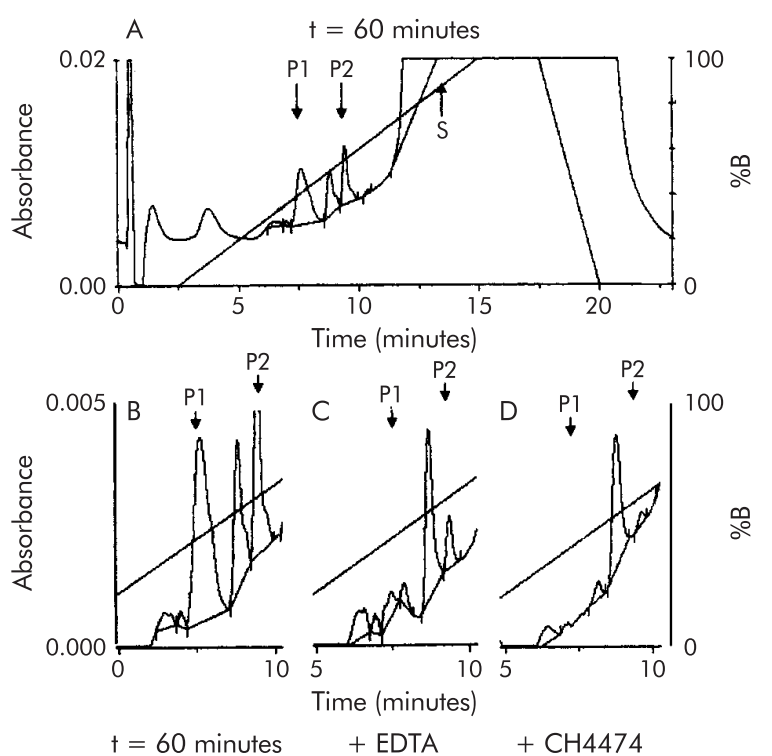

Figure 2 Hydrolysis of an unlabelled oligopeptide substrate mimicking pro-tumour necrosis factor $\alpha$ (pro-TNF- $\alpha$ ) cleavage by detergent extracts of cell membranes from human colonic mucosa. Substrate (S) hydrolysis was analysed by reverse phase high pressure liquid chromatography and the cleavage products (P1, P2) were identified by synthetic standards (A). (B) Magnification of product formation. (C, D) Inhibition by EDTA (5 mM) and CH4474 $(1 \mathrm{\mu g} / \mathrm{ml})$. Similar results were obtained in five further independent experiments.

the amount of detergent extract added and for time up to one hour (data not shown). As summarised in fig 3, EDTA and CH4474 also inhibited cleavage of the dnp labelled oligopeptide, and a representative chromatogram of the effect of $\mathrm{CH} 4474$ is shown in fig 4 . Another zink chelating agent, phenantrolin, and BB94, a MMP/TACE inhibitor, had similar effects (fig 3). Surprisingly, TLCK also inhibited peptide cleavage but other serine protease inhibitors, such as leupeptin, had no effect (data not shown). TLCK not only inhibited enzyme activity in detergent extract but also the effect of recombinant TACE on GST-pro-TNF- $\alpha$ cleavage (fig 5). Phenyl methyl sulphonyl fluoride, bacitracin, and glycerol up to $20 \%$ had no effect (data not shown). The same was true for trocade, a broad spectrum MMP inhibitor, which failed to inhibit peptide hydrolysis at concentrations $(5 \mu \mathrm{M})$ known to inhibit several MMPs, but not TACE (fig 3). ${ }^{22}$

\section{Localisation and expression of TACE protein in human colonic mucosa}

Using immunohistochemistry, we found that TACE appeared to be predominantly expressed in mononuclear cells of the lamina propria and in the epithelium (fig 6A, C). No significant staining was seen in control sections stained with a goat immunoglobulin (fig 6B, D). To corroborate this finding, western blotting was performed on detergent extracts of cell membranes from epithelial cells and LPMNC isolated from normal human colonic biopsies. The full length proform as well as the active form of TACE with molecular weights of about $110 \mathrm{kDa}$ and $85 \mathrm{kDa}$, respectively, were identified in both cell types (fig 7). The proform appeared to consist of at least two bands, which may be due to differences in glycosylation, as reported previously. ${ }^{27}$ Immunoreactivity disappeared when the primary antibody was preincubated with an epitope specific blocking peptide.

\section{Measurement of TACE activity in colonic mucosa from patients with IBD}

The dnp labelled oligopeptide assay was used to measure TACE activity in IBD patients because sample interference was

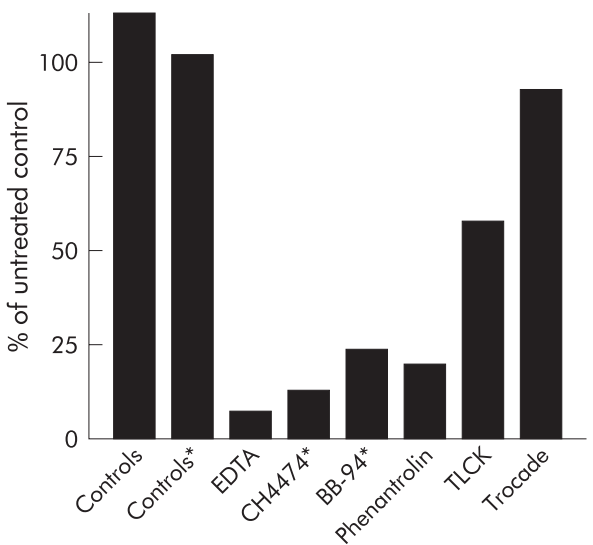

Figure 3 Effect of protease inhibitors on tumour necrosis factor $\alpha$ (TNF- $\alpha$ ) converting enzyme (TACE) activity in detergent extracts of cell membranes from human colonic mucosa, as measured by hydrolysis of a dinitrophenol labelled oligopeptide substrate mimicking the pro-TNF- $\alpha$ cleavage site. TACE activity was quantitated by high pressure liquid chromatography and expressed relative to protein concentration. Mean values of three individual experiments of material pooled from individual patients are shown. Samples contained dimethylsulphoxide (DMSO) $0.05 \%(*)$ when necessary for solubilisation of the inhibitors. Controls with $\left({ }^{*}\right)$ and without DMSO are shown. TLCK, No-p-tosyl--lysine chloromethyl ketone.
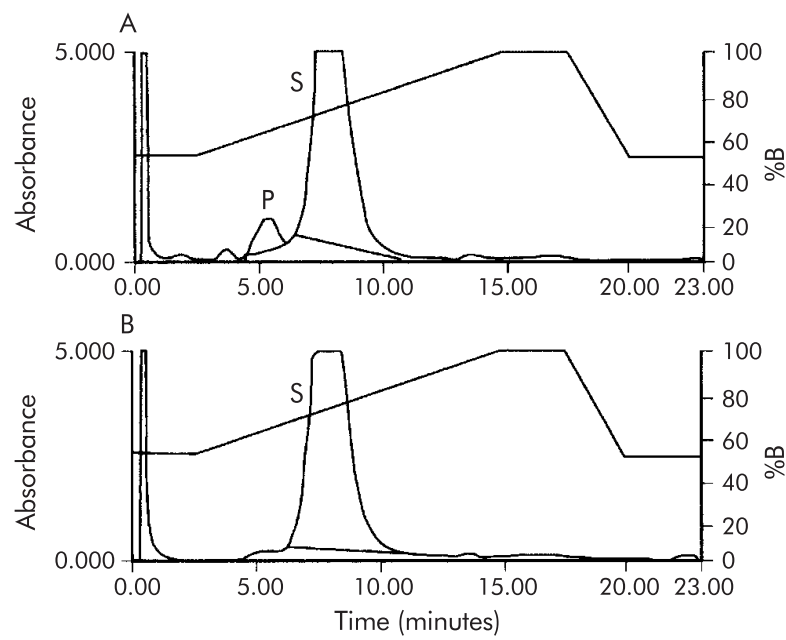

Figure 4 Hydrolysis of a dinitrophenol (dnp) labelled peptide substrate mimicking the pro-tumour necrosis factor $\alpha$ (pro-TNF- $\alpha$ ) cleavage site by detergent extracts of cell membranes from human colonic mucosa. Substrate (S) hydrolysis was analysed by reverse phase high pressure liquid chromatography and the dnp labelled cleavage product $(\mathrm{P})$ was identified by synthetic standard (A). (B) Product formation was inhibited by CH4474 $(1 \mathrm{\mu g} / \mathrm{ml})$.

avoided, which simplified analyses. The median TACE activity level was significantly increased in patients with ulcerative colitis ( $118 \mathrm{AU} / \mathrm{mg}$, range $67-337, \mathrm{n}=18$ ) compared with controls (79 AU/mg, range 60-130, $\mathrm{n}=12)(\mathrm{p}<0.01)$. Breakdown according to the grade of clinical activity showed that the median TACE level was higher in those with clinically active ulcerative colitis ( $147 \mathrm{AU} / \mathrm{mg}$, range $73-337, \mathrm{n}=12$ ) compared with controls $(\mathrm{p}<0.01)$ but not in those with inactive disease (94 AU/mg, range 67-123, n=6) (NS). In contrast, the median TACE level in patients with Crohn's disease $(81 \mathrm{AU} / \mathrm{mg}$, range $50-166, n=10$ ) did not differ from that in controls (fig 8), irrespective of disease activity (NS). There was no overall difference in median TACE levels between samples obtained from endoscopically normal areas ( $106 \mathrm{AU} / \mathrm{mg}$, range 77-158, $\mathrm{n}=18$ ) and areas with macroscopically active Crohn's disease 


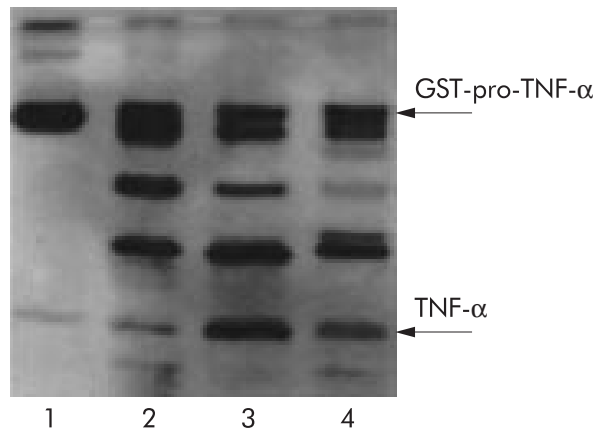

Figure 5 Sodium dodecyl sulphate (SDS) electrophoresis showing hydrolysis of glutathione-S-transferase-pro-tumour necrosis factor $\alpha$ (GST-pro-TNF- $\alpha$ ) by recombinant TNF- $\alpha$ converting enzyme (TACE) Samples were analysed on continuous SDS polyacrylamide gels $(20 \%)$ using silver staining. Lane 1: GST-pro-TNF- $\alpha$ substrate; lane 2 : recombinant TACE, $\mathrm{t}=0$ minutes; lane 3: recombinant TACE, $\mathrm{t}=60$ minutes; lane 4: recombinant TACE, $\mathrm{t}=60$ minutes + No-p-tosyl--lysine chloromethyl ketone (TLCK $10 \mu \mathrm{g} / \mathrm{mll}$ ). Similar results were obtained in two further independent experiments.

or ulcerative colitis disease (90 AU/mg, range 70-136, $\mathrm{n}=10$ ) (NS). However, separate analysis of paired biopsies from five patients with ulcerative colitis and one with Crohn's disease showed that median TACE levels were slightly higher in endoscopically inflamed areas ( $77 \mathrm{AU} / \mathrm{mg}$, range 66-144) compared with normal mucosa (65 AU/mg, range 27-106) $(\mathrm{p}<0.05)$.

\section{DISCUSSION}

In this study, we found that detergent extracts of cell membranes from normal human colonic mucosa cleaved a full length pro-TNF- $\alpha$ substrate and released TNF- $\alpha$. As release of TNF- $\alpha$ was sensitive to both EDTA and a TACE/MMP inhibitor, ${ }^{22}{ }^{23}$ we concluded that biopsies contained TACE-like activity (fig 1). Next, we found that detergent extracts also cleaved a synthetic peptide mimicking the hydrolysis site for
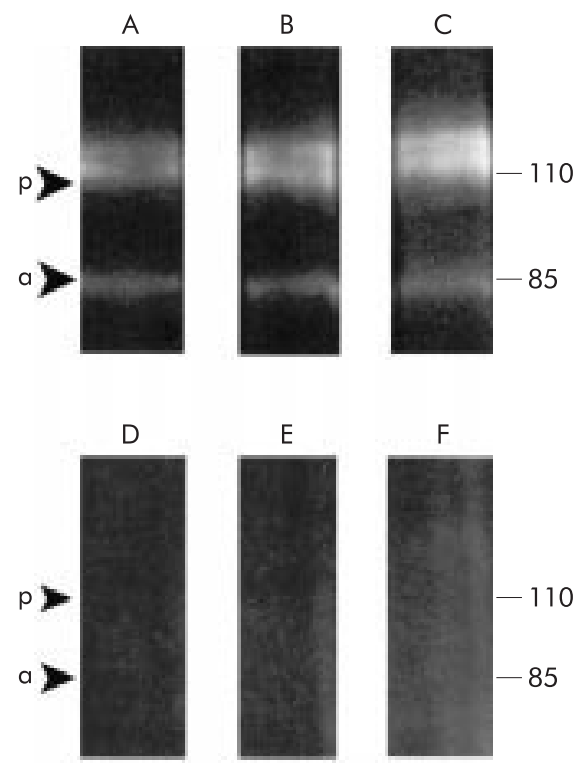

Figure 7 Western blotting of tumour necrosis factor $\alpha$ (TNF- $\alpha$ ) converting enzyme (TACE) protein immunoreactivity in detergent extract of membranes from intact biopsies (lane A), isolated epithelial cells (lane B), or purified lamina propria mononuclear cells (lane C). The arrows indicate the proform (p) and active (a) forms of TACE. Lanes $D$ and $E$ show the absence of immunoreactivity when an epitope mimicking blocking peptide was present during incubation. The TACE antibody was the same as that used in fig 6 . Similar results were obtained in three independent experiments.

TACE in the pro-TNF- $\alpha$ sequence at amino acids 76-77. From these data we concluded that biopsies contained TACE-like activity that cleaves a model peptide for the human TNF- $\alpha$ precursor at the correct site (fig 2). Finally, we used a dnp labelled oligopeptide assay to study the effect of inhibitors. The effect of these was as predicted (fig 3) (19 $^{29-31}$ with the
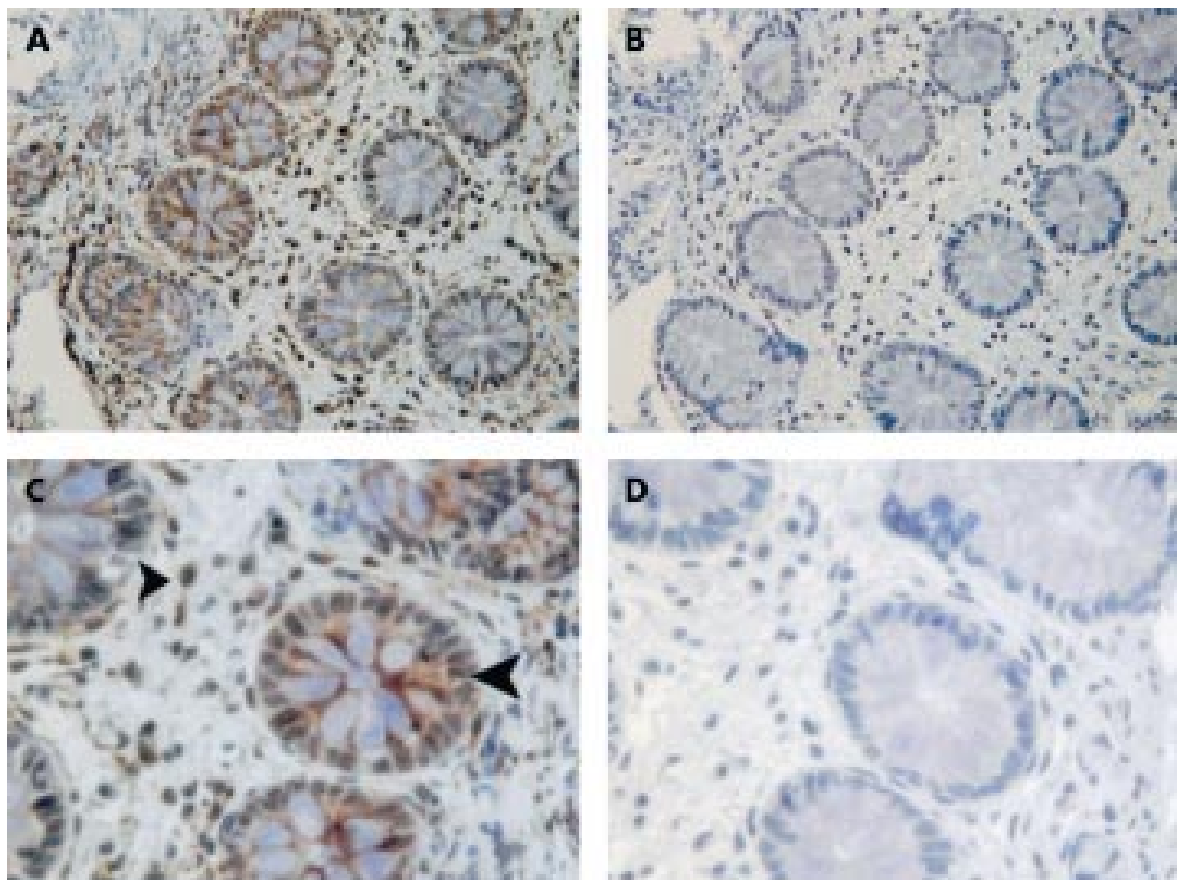

Figure 6 Immunohistochemistry of tumour necrosis factor $\alpha$ (TNF- $\alpha$ ) converting enzyme (TACE) protein expression in normal human colonic mucosa. (A) $(\times 20)$ and $(C)(\times 80)$ show that TACE was widely expressed in lamina propria mononuclear cells and in crypt epithelial cells. (B) $(\times 20)$ and (D) $(\times 80)$ show the corresponding background staining when the primary antibody was substituted with unspecific goat immunoglobulins. Examples of cells regarded as positive for TACE are indicated by arrows (C). Similar results were obtained in two independent experiments. 


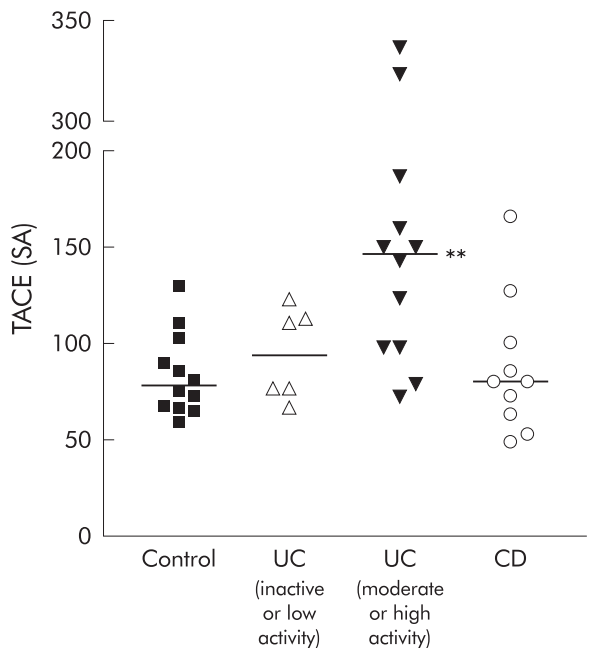

Figure 8 Tumour necrosis factor $\alpha$ (TNF- $\alpha$ ) converting enzyme (TACE) activity in detergent extracts of cell membranes from colonic mucosa from patients with ulcerative colitis (UC) or Crohn's disease (CD) and healthy controls. TACE activity is expressed as specific activity (SA) in arbitrary units per $\mathrm{mg}$ of protein based on high pressure liquid chromatography analysis of hydrolysis of a dinitrophenol labelled oligopeptide assay substrate mimicking the pro-TNF- $\alpha$ cleavage. Horizontals lines indicate median values. $* * p<0.01$

exception of TLCK, which may be regarded as an unspecific TACE inhibitor (fig 5). Purified matrilysin, stromelysin, collagenase, the gelatinases, as well as membrane type (MT)MMPs have been shown to cleave pro-TNF- $\alpha$ to soluble TNF- $\alpha$ in vitro. ${ }^{19} 32$ It is therefore important that trocade, an inhibitor of several MMPs, but not TACE itself, was ineffective even at concentrations fivefold above those required for inhibition of stromelysin-1 (MMP-3) and many fold above those needed to inhibit several other MMPs. ${ }^{22} 23$ Taken together, our results show that an enzyme with functional properties similar to TACE is present in human colonic mucosa and presumably responsible for TNF- $\alpha$ processing.

Next we used immunohistochemistry to localise TACE protein in human colonic mucosa. TACE protein was, as expected, widely expressed in LPMNC ${ }^{10}{ }^{33}$ but immunoreactivity was also present in the epithelium (fig 6). These data were confirmed by western blotting of cell membrane protein from purified human colonic epithelial cells or LPMNC showing that both cell fractions expressed the proform as well as the active form of $\mathrm{TACE}^{28}$ ( fig 7). The latter observation is consistent with the recent demonstration of a correlation between TACE and CD68 antigen expression in synovial tissue cells. ${ }^{33}$ The presence of TACE protein in human colonic epithelial cells has not been described previously but this is not surprising in light of the ubiquitous expression of this sheddase in a variety of non-immune human cells, including endothelial cells, small muscle cells, and chondrocytes. ${ }^{1013}$ Interestingly, tace ${ }^{\Delta \mathrm{Zn} / \Delta \mathrm{Zn}}$ (knockout) mice are characterised by several cellular shedding defects and display a range of epithelial abnormalities, including blunted small bowel villi and pseudostratification of the mucosal epithelium. ${ }^{34}$ Further study is required to characterise the function of TACE protein expressed in human colonic epithelial cells. ${ }^{35}$

Functional TACE activity was increased in patients with ulcerative colitis, particularly in those with clinically active disease (fig 8). This accords with our previous demonstration of a modest but significant twofold increase in mucosal TACE mRNA levels in an entirely different sample of patients with ulcerative colitis. ${ }^{15}$ Hence both mRNA expression and TACE activity appear to be elevated in ulcerative colitis patients. Moreover, the level of enzyme activity was somewhat higher in areas with endoscopically active inflammation when patients were their own controls. Interestingly, similar changes have recently been demonstrated in arthritis affected cartilage as well as in synovial tissue of patients with rheumatoid arthritis. ${ }^{33}{ }^{36}$ TACE activity was also present in Crohn's disease mucosa but not increased compared with controls (fig 8). This contrasts our previous finding of a correlation between TACE mRNA expression and Crohn's disease activity ${ }^{15}$ and one possibility is that inactivation of TACE activity has been catalysed in Crohn's disease mucosa by other MMPs as part of a self-regulatory mechanism similar to that described for MTlMMP-MMP-2 interactions. ${ }^{37}$ Increased mRNA expression, but not increased enzyme activity, would be detected in such a setting. Recently, phorbol 12-myristate-13-acetate, a potent inducer of shedding, has been shown to downregulate TACE expression in vitro, and since the effect was inhibited by a MMP inhibitor, shedding processes appear to be under feedback control. ${ }^{38}$ Whether a similar downregulatory mechanism is operative in vivo in Crohn's disease mucosa, but not in ulcerative colitis, remains purely speculative at this stage.

Inhibition of TACE activity strongly downregulates T cell release of soluble TNF- $\alpha$ in vitro, which may lead to accumulation of the membrane bound precursor ${ }^{10} 30$ thought to be biologically active. ${ }^{39}$ Shedding of downregulatory soluble TNF- $\alpha$ receptors is also compromised and TACE/MMP inhibition may in theory carry a proinflammatory potential. ${ }^{13}$ However, a recent study showed that oral administration of a potent MMP/TACE inhibitor to healthy human subjects strongly reduced lipopolysaccharide induced TNF- $\alpha$ release without influencing the level of monocyte bound TNF- $\alpha{ }^{40}$ Synthetic MMP inhibitors have been shown to downregulate inflammation in rat models of arthritis ${ }^{41}$ and $\mathrm{IBD}^{42-43}$ and to protect against endotoxic shock in mice by preventing TNF- $\alpha$ processing. ${ }^{44}$ Although the MMP inhibitors tested have a variable ability to block sheddase enzyme activity, the data make it less likely that this class of drugs have a general proinflammatory effect in vivo. Shedding of L-selectin and transforming growth factor $\alpha$ is also compromised in TACE deficient mice ${ }^{38}$ and MMP inhibitors reduce the release of the soluble Fas ligand by $\mathrm{T}$ cells in vitro, ${ }^{45}$ but the exact clinical significance of these effects remains unclear.

In conclusion, we have shown that functional TACE activity is ubiquitously expressed in normal or Crohn's disease colonic mucosa and upregulated in ulcerative colitis. Secretion of TNF- $\alpha$ is definitively increased in $\operatorname{IBD}^{2647-49}$ and drugs targeting the final stage of TNF- $\alpha$ processing may therefore be of benefit. As TACE is structurally related to the family of MMPs, which have been strongly implicated as final mediators of TNF- $\alpha$-induced proteolytic gut mucosal damage, ${ }^{16-18} 50$ our data may be helpful in creating a rationale for therapeutic intervention in ulcerative colitis using specifically tailored synthetic MMP inhibitors that also target TACE.

\section{ACKNOWLEDGEMENTS}

Gitte Pedersen is the recipient of a research fellowship from the University of Copenhagen. Pia Foegh and Christina Ellervik have received research grants from P Carl Petersens Foundation, and Povl Riis and Vibeke Binders Foundation. Tove Kirkegaard is the recipient of an Industrial PhD grant from the Danish Academy of Technical Science (ATV). The technical assistance of Mrs Hanne Fuglsang and the technician staff at Laboratory of Gastroenterology 54O3, Herlev University Hospital, Denmark is greatly appreciated. We thank Eva Gaarsdal, Laboratory of Haematology 54P4, Herlev University Hospital for technical assistance in fluorescent flow cytometry experiments, Mrs Bente Therkildsen and Mrs Birthe Andersen, Osteopro A/S, Copenhagen, Denmark for technical assistance in the immunohistochemical studies, and Alastair Hansen, Department of Pathology, Herlev Hospital for analysis of immunohistochemical stainings. Alistair Bingham is an employee at Celltech Chiroscience, Cambridge, UK. This study has not received financial support from Celltech Chiroscience or any drug manufacturing company. 


\section{Authors' affiliations}

J Brynskov, P Foegh, G Pedersen, C Ellervik, T Kirkegaard, T Saermark, Department of Medical Gastroenterology C, Herlev Hospital, University of Copenhagen, Denmark

A Bingham, Celltech Chiroscience, Cambridge, UK

Part of this study was accepted for presentation at: "A New York Academy of Sciences Conference. Inhibition of Matrix

Metalloproteinases: Therapeutic Applications", Tampa, FL, 1998; Digestive Disease Week (DDW) 1999, Orlando, FL; and Digestive Disease Week (DDW) 2000, San Diego (poster of distinction), including AGA Poster of Distinction CD-ROM (Marathon Multimedia, Inc.).

\section{REFERENCES}

1 Targan SR, Hanaver SB, van Deventer SJH, et al. A short-term study of chimeric monoclonal antibody cA2 to tumour necrosis factor $\alpha$ for Crohn's disease. N Engl J Med 1997;337:1029-35

2 Stack WA, Mann SD, Roy AJ, et al. Randomised controlled trial of CDP571 antibody to tumour necrosis factor- $\alpha$ in Crohn's disease. Lancet 1997;349:521-4.

3 Baert FJ, D'Haens GR, Peeters M, et al. Tumor necrosis factor $\alpha$ antibody (Infliximab) therapy profoundly down-regulates the inflammation in Crohn's ileocolitis. Gastroenterology 1999;116:22-8.

4 D'Haens G, van Deventer S, Van Hogezand R, et al. Endoscopic and histological healing with infliximab anti-tumor necrosis factor antibodies in Crohn's disease: a European multicenter trial. Gastroenterology 1999:116:1029-34

5 Rutgeerts $\mathbf{P}, D^{\prime}$ Haens $G$, Targan S, et al. Efficacy and safety of retreatment with anti-tumor necrosis factor antibody (infliximab) to maintain remission in Crohn's disase. Gastroenterology 1999;117:761-9.

6 Present DH, Rutgeerts P, Targan S, et al. Infliximab for the treatment of fistulas in patients with Crohn's disease. N Engl J Med 1999;340: 1398-405.

7 Sandborn WJ, Feagan BG, Hanauer SB, et al. An engineered human antibody to TNF (CDP571) for active Crohn's disease: A randomized double-blind placebo-controlled trial. Gastroenterology $2001 ; 120 ; 1330-8$

8 Evans RC, Clarke L, Heath P, et al. Treatment of ulcerative colitis with an engineered human anti-TNF $\alpha$ antibody CDP571. Aliment Pharmacol Ther 1997;11:1031-5.

9 Bell SJ, Kamm MA. Review article: the clinical role of anti-TNF $\alpha$ antibody treatment in Crohn's disease. Aliment Pharmacol Ther 2000;14:501-14.

10 Black RA, Rauch CT, Kozlosky CJ, et al. A metalloproteinase disintegrin that releases tumour-necrosis factor- $\alpha$ from cells. Nature 1997;385:729-33.

11 Moss ML, Jin S-LC, Mills ME, et al. Cloning of a disintegrin metalloproteinase that processes precursor fumour-necrosis factor- $\alpha$. Nature 1997;385:733-5.

12 Black RA, White JM. ADAMs: focus on the protease domain. Curr Opin Cell Biol 1998; 10:654-9.

13 Killar L, White J, Black R, et al. Adamalysins. A family of metzincins including TNF-alpha converting enzyme (TACE). Ann NY Acad Sci 1999;878:442-52

14 Yamamoto S, Higuchi Y, Yoshiyama K, et al. ADAM family proteins in the immune system. Immunol Today 1999;20:278-84

15 Føgh P, Ellervik C, Særmark T, et al. TNF-alpha-converting enzyme activity in colonic biopsy specimens from patients with inflammatory bowel disease revealed by mRNA and in vitro assay. Ann NY Acad Sci 1999;878:692-5.

16 Baugh MD, Perry M, Hollander AP, et al. Matrix metalloproteinase levels are elevated in inflammatory bowel disease. Gastroenterology 1999;117:814-22

17 Heuschkel RB, MacDonald TT, Monteleone G, et al.. Imbalance of stromelysin-1 and TIMP-1 in the mucosal lesions of children with inflammatory bowel disease. Gut 2000;47:57-62.

18 von Lampe B, Barthel B, Coupland SE, et al. Differential expression of matrix metalloproteinases and their tissue inhibitors in colon mucosa of patients with inflammatory bowel disease. Gut 2000;47:63-73.

19 Gearing AHJ, Beckett M, Christodoulou M, et al. Matrix metalloproteinases and processing of pro-TNF- $\alpha$. J Leukocyte Biol 1995:57:774-7

20 Langholz E, Munkholm P, Davidsen M, et al. Course of ulcerative colitis: analysis of changes in disease activity over years. Gastroenterology 1994; 107:3-11.

21 Munkholm P, Langholz E, Nielsen $\mathrm{OH}$, et al. Incidence and prevalence of Crohn's disease in the county of Copenhagen, 1962-87: a sixfold increase in incidence. Scand J Gastroenterol 1992;27:609-14.

22 Sugita K. Recent advances in inhibitors of matrix metalloproteinases for cancer therapy. Drugs 1999;2:327-39

23 Beckett RP, Whittaker M. Matrix metalloproteinase inhibitors 1998. Exp Opin Ther Patents 1998:8:259-82.

24 Pedersen G, Saermark T, Giese B, et al. A simple method to establish short-term cultures of normal human colonic epithelial cells from endoscopic biopsy specimens. Comparison of isolation methods, assessment of viability and metabolic activity. Scand J Gastroenterol 2000;35:772-80

25 Pedersen B, Saermark T, Bendtzen K, et al.. Cultures of human colonic epithelial cells isolated from patients with inflammatory bowel disease. Effect of IFN $\gamma$, TNF $\alpha$ and IL-1 $\beta$ on viability, butyrate oxidation and IL-8 secretion. Autoimmunity 2000;32:255-63.

26 Reinecker HC, Steffen M, Witthoeft T et al. Enhanced secretion of tumour necrosis factor-alpha, IL-6, and IL-1 beta by isolated lamina propria mononuclear cells from patients with ulcerative colitis and Crohn's disease. Clin Exp Immunol 1993;94:174-81.

27 Skovronsky DM, Moore DB, Milla ME, et al. Protein kinase C-dependent alpha-secretase competes with beta-secretase for cleavage of amyloid-beta precursor protein in the trans-golgi network. J Biol Chem 2000;275:2568-75

28 Schlondorff J, Becherer JD, Blobel CP. Intracellular maturation and localization of the tumour necrosis factor alpha convertase (TACE). Biochem J 2000;347:131-8.

29 Elwood PC, Deutsch JC, Kolhouse JF. The conversion of the human membrane-associated folate binding protein (folate receptor) to the soluble folate binding protein by a membrane-associated metalloproteinase. J Biol Chem 1991;266:2346-53.

30 Mohler KM, Sleath PR, Fitzner JN, et al. Protection against a lethal dose of endotoxin by an inhibitor of tumour necrosis factor processing. Nature 1994;370:218-20.

31 Gearing AHJ, Beckett $M$, Christodoulou $M$, et al. Processing of tumour necrosis factor- $\alpha$ by metalloproteinases. Nature 1994;370:555-7.

32 d'Ortho MP, Will H, Atkinson S, et al. Membrane-type matrix metalloproteinases 1 and 2 exhibit broad-spectrum proteolytic capacities comparable to many matrix metalloproteinases. Eur J Biochem 1997:250:751-7

33 Ohta $S$, Harigai $M$, Tanaka $M$, et al. Tumor necrosis factor- $\alpha$ (TNF- $\alpha$ ) converting enzyme contributes to production of TNF- $\alpha$ in synovial tissues from patients with rheumatoid arthritis. J Rheumatol 2001;28:1756-63.

34 Peschon JJ, Slack JL, Reddy T, et al. An essential role for ectodomain shedding in mammalian development. Science 1998;282:1281-4.

35 Kirkegaard T, Pedersen G, Saermark T, et al. Expression and functional activity of tumor necrosis factor (TNF) $\alpha$ converting enzyme (TACE) in human colonic epithelial cells. Gastroenterology 2001;120(suppl 1):A3 16.

36 Patel IR, Attur MG, Patel RN. TNF- $\alpha$ convertase enzyme from human arthritis-affected cartilage: isolation of cDNA by differential display expression of the active enzyme, and regulation of TNF- $\alpha$. J Immunol 1998;160:4570-9.

37 Murphy G, Knäuper V, Cowell S, et al. Evaluation of some newer matrix metalloproteinases. Ann NY Acad Sci 1999:878:25-39.

38 Doedens JR, Black RA. Stimulation-induced down-regulation of tumor necrosis factor- $\alpha$ converting enzyme. J Biol Chem 2000;275:14598607.

39 Scallon BJ, Aravalo Moore M, et al.. Chimeric anti-TNF $\alpha$ monoclona antibody cA2 binds recombinant transmembrane TNF- $\alpha$ and activates immune effector functions. Cytokine 1995;7:251-9.

40 Dekkers PEP, Lauw FN, ten Hove T, et al. The effect of a metalloproteinase inhibitor (GI5402) on tumour necrosis factor- $\alpha$ (TNF $\alpha$ ) and TNF- $\alpha$ receptors during human endotoxemia. Blood 1999:94:2252-8.

41 McGeehan GM, Becherer JD, Bast RC, et al. Regulation of tumour necrosis factor-alpha processing by a metalloproteinase inhibitor. Nature 1994;370:558-61.

42 Sykes AP, Bhogal R, Brampton C, et al. The effect of an inhibitor of matrix metalloproteinases on colonic inflammation in a trinitrobenzenesulphonic acid rat model of inflammatory bowel disease. Aliment Pharmacol Ther 1999;13:1535-42.

43 Di Sebastino P, Mascetta G, Artese L, et al. Batimastat, a matrix metalloproteinase inhibitor, accelerates healing in rat experimenta colitis. Gastroenterology 1999;116:G3942.

44 Solorzano CC, Ksontini R, Pruitt JH, et al. A matrix metalloproteinase inihibitor prevents processing of tumour necrosis factor alpha (TNF alpha) and abrogates endotoxin induced lethality. Shock 1997;7;427-31.

45 Kayagaki N, Kawasaki A, Ebata T, et al. Metalloproteinase-mediated release of human Fas ligand. J Exp Med 1995;182:1777-83.

46 MacDonald TT, Hutchings $P$, Choy MY, et al. Tumour necrosis factor-alpha and interferon-gamma production measured at the single level in normal and inflamed human intestine. Clin Exp Immunol 1990:81:301-5.

47 Murch SH, Braegger CP, Walker-Smith JA, et al. Location of tumour necrosis factor $\alpha$ by immunohistochemistry in chronic inflammatory bowe disease. Gut 1993;34:1705-9.

48 Breese EJ, Michie CA, Nicholls SW, et al. Tumour necrosis factor alpha-producing cells in the intestinal mucosa of children with inflammatory bowel disease. Gastroenterology 1994;106: 1455-66.

49 Schreiber S, Nikolaues S, Hämling J, et al. Tumour necrosis factor $\alpha$ and interleukin $1 \beta$ in relapse of Crohn's disease. Lancet 1999;353:459-61.

50 Pender S LF, Fell JME, Chamow SM, et al. A p55 TNF receptor immunoadhesin prevents T cell-mediated intestinal injury by inhibiting matrix metalloproteinase production. J Immunol 1998; 160:4098-103. 